\section{Final Curtain}

The dramaturgical approach to teaching reconstructs the traditional classroom and transforms it, changing it from a predictable, fixed environment into a complex, multilayered environment where even the most apparent truths may be subject to scrutiny. It exploits the benefits of the artistic perspective to cast light upon politics and foster learning. "Artistic performances generate tensions which we can resolve only by becoming alive to new ways of viewing the world. They detach us from old ways. They change our loyalties. De-eroticizing our old involvements, they alienate us from whatever objectives we have embraced with singular intensity" (Kariel 1977, 61). The dramaturgical approach encourages student involvement, challenges assumptions about teaching, and provides an alternative model for understanding political behavior.
Fully implementing the dramaturgical approach requires considerable effort on the part of the professor and the students. In addition, it requires support from administrators who are willing to stand behind teachers who wish to innovate in the classroom. But aside from issues of time, energy, and support, political science professors must be open to new ways of approaching old subjects if they wish to enliven the subject matter and the classroom.

\section{References}

Edelman, Murray. 1988. Constructing the Political Spectacle. Chicago: University of Chicago Press.

Goffman, Erving. 1959. The Presentation of Self in Everyday Society. Garden City, NY: Doubleday Anchor Books.

Kariel, Henry S. 1977. Beyond Liberalism,

\title{
Learning Styles of Political Science Students
}

\author{
Richard L. Fox, Union College \\ Shirley A. Ronkowski, University of California, Santa Barbara
}

The perennial struggle to reach out to our students and engage their minds is something that plagues all college and university faculty. Political science instructors may have a slight advantage over instructors in other fields in connecting with students since our subject matter focuses on clashing ideas which can directly affect the lives of our students. Nonetheless, the teaching of political science presents many of the same dilemmas faced by instructors in every discipline. We want to bring theoretical material to life for students, choose case studies relevant to their lives, and excite them about the important questions in our respective fields. Our angst and frustration over our teaching almost always seem to focus on changing instructor style and technique. Should I change the format of the class? Should I revise the assignments? Should I change my method of presentation? By asking ourselves only these questions, we overlook the variety of ways in which students conceptualize and process information and ideas. Understanding various student learning styles can be helpful in designing instruction that engages students by appealing to their particular learning abilities. In the present analysis we will examine the learning profiles of students in political science courses at a private liberal arts college. Our underlying assumption is that the more we know about our students and their learning styles, the better we will be able to design instruction that allows students to make use of their strengths and not be unduly hampered by their learning weaknesses.

\section{Method of This Study}

Student learning styles and preferences have been extensively studied, and many types of learning style
Where Relations Grow. San Francisco: Chandler \& Sharp Publishers.

Vonnegut, Kurt. 1968. "Who Am I This Time?" In Welcome to the Monkeyhouse. NY: Delacorte Press.

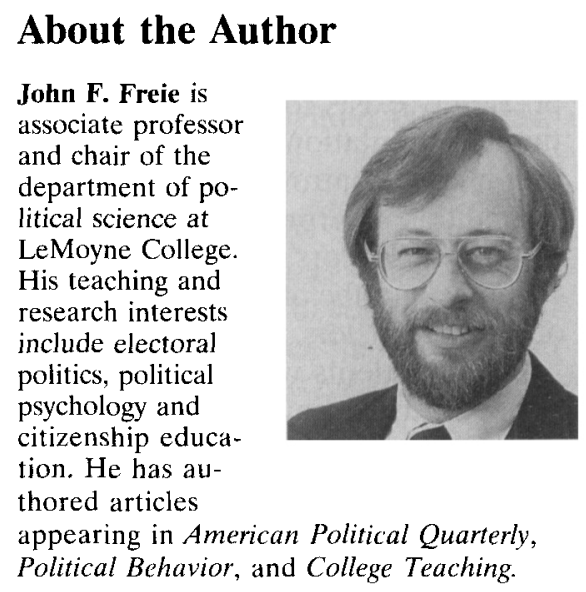

John F. Freie is associate professor and chair of the department of political science at LeMoyne College. His teaching and research interests include electoral politics, political psychology and citizenship educathored articles Political Behavior, and College Teaching. models have been developed. Various models and accompanying inventories have been designed and classified based on one of three preference areas: information processing, environmental, and personality related (Hickcox 1995). The information processing model developed by David Kolb $(1984,1985)$ is the one we favor, having used it successfully over the past six years in our own teaching. Kolb's Experiential Learning Cycle, and accompanying Learning Style Inventory (LSI), have been extensively analyzed, tested, and critiqued as evidenced by the 679 citations of Kolb's work listed in the Social Sciences Citation Index between 1971 and 1989 (Hickcox 1991, 4). The majority of these studies and critiques, particularly those focused on the LSI in higher education, give positive support; "criticisms usually center on psychometric issues, and it should be noted that even the most critical studies of 
the LSI are not entirely unsupportive of the theory" (Hickcox 1991, 319-20).

In conducting the present study, we were interested in learning whether a variety of learning styles are typically evinced by students in political science courses and how evenly students are distributed in their preference for learning styles. The only expectations we had were that (1) there would probably be a greater diversity of learning styles among students in lower division courses than upper division courses since students may self-select their majors in accordance with their learning preferences, and (2) political science students would tend to prefer a particular style of learning (Kolb 1984, 86).

To examine the distribution of learning styles among students in political science courses, we administered the LSI to the 260 students enrolled in the eleven political science courses offered at Union College during the spring term of 1995. Five of the courses were introductory level, with predominantly lower-division students and a low proportion of political science majors. The six upper division courses had a much larger proportion of political science majors. In addition to the LSI, students were given a brief questionnaire soliciting demographic information (e.g., major, sex, class level, and study habits). We also collected some demographic information about the student body. The average combined SAT score of a student at Union College is around 1150 (530 verbal and 620 math). Roughly $45 \%$ of Union students were in the top $10 \%$ of their high school class, and $98 \%$ were in the top half of their high school class. Over $80 \%$ of the students are from New York State or the New England area, and only $2 \%$ of the students are international. The sample of students at Union is quite homogenous; with an above-average socioeconomic status and with few ethnic and racial minorities. Thus, if we find a broad range in the learning styles among the Union students, we could be fairly certain of finding at least the same (and probably larger) range in more heterogeneous student groups.

\section{Background: Kolb Learning Style Model}

The Kolb learning model builds on the learning theories of Dewey, Lewin, and Piaget and takes into account experience, perception, cognition, and behavior as the critical elements in the learning process (Kolb 1984, 20). Based on a fourstage Experiential Learning Cycle, the model depicts learning as occurring in four consecutive stages in which learners (1) encounter the work through a concrete experience; (2) reflect on and make observations about those experiences; (3) develop abstract conceptualizations from those reflections; and (4) conduct active experimentation on those conceptualizations through evaluating, testing, and applying their generalizations (Kolb 1984, 21; see Figure 1).

This model focuses on how students most readily perceive information to be learned and how they prefer to process that information. Perception that relies on concrete experience involves feeling, sensing, and personal involvement with the material and often with the instructor. Perception that relies on abstract conceptualization emphasizes thought, symbols, and models. Students usually have a preference for one style of perception or the other, although the ideal student would be equally facile in both and rely upon the type of perception most conducive to learning in a particular situation.

As for processing information, some students naturally gravitate toward reflective observation. This method of processing requires patience, objectivity, and careful judgment. Opinions are formed through reflection on thoughts and feelings. Students who process new information best through active experimentation require active involvement (e.g., some form of manipulation) with the physical or abstract material to be learned. Opinions are formed through one's own experiences.

Combining these two dimensions of perceiving (grasping) and processing (transforming), Kolb defines four types of learners (see Figure 2).

These four learner types are described as follows:

\section{Diverger \\ Combines concrete experience and reflective observation \\ "People with this learning style are best at viewing or reflecting on concrete situations from many dif- ferent points of view. Their ap- proach to situations is to observe rather than take action" (Kolb 1985, 7).}

Figure 1 - Four-Stage Experiential Learning Cycle 


\begin{abstract}
Assimilator
Combines abstract conceptualization and reflective observation "People with this learning style are best at understanding a wide range of information and putting it into concise, logical form.... Generally, people with this learning style find it more important that a theory have logical soundness than practical value" (1985, 7).
\end{abstract}

\section{Converger}

Combines abstract conceptualization and active experimentation "People with this learning style are best at finding practical uses for ideas and theories.... [They] have the ability to solve problems and make decisions based on finding solutions to questions or problems.... [They] would rather deal with technical tasks and problems than with social and interpersonal issues" $(1985,7)$.

\section{Accommodator}

Combines concrete experience and active experimentation

"People with this learning style have the ability to learn primarily from 'hands-on' experience.... [They] enjoy carrying out plans and involving... [themselves] in new and challenging experiences.... [Their] tendency maybe to act on 'gut' feelings rather than on logical analysis" $(1985,7)$.

As with most typologies, it is possible for these categories of learning to overlap so that a learner may have more than one favorite learning style or not have a strong preference for any one particular style. The most accomplished learners are able to use the learning style best suited to a given learning situation.

\section{Results}

The Learning Styles Inventory (LSI) consists of 12 statements, each of which has four possible endings. The test-taker is asked to rank order the four sentence endings, give a " 4 " to the ending that best describes the situation in which the learner learns best, down to a " 1 " for the ending that describes the learner's least preferred scenario. Thus, the lowest raw

Figure 2 - Learning Modes and Learning Styles

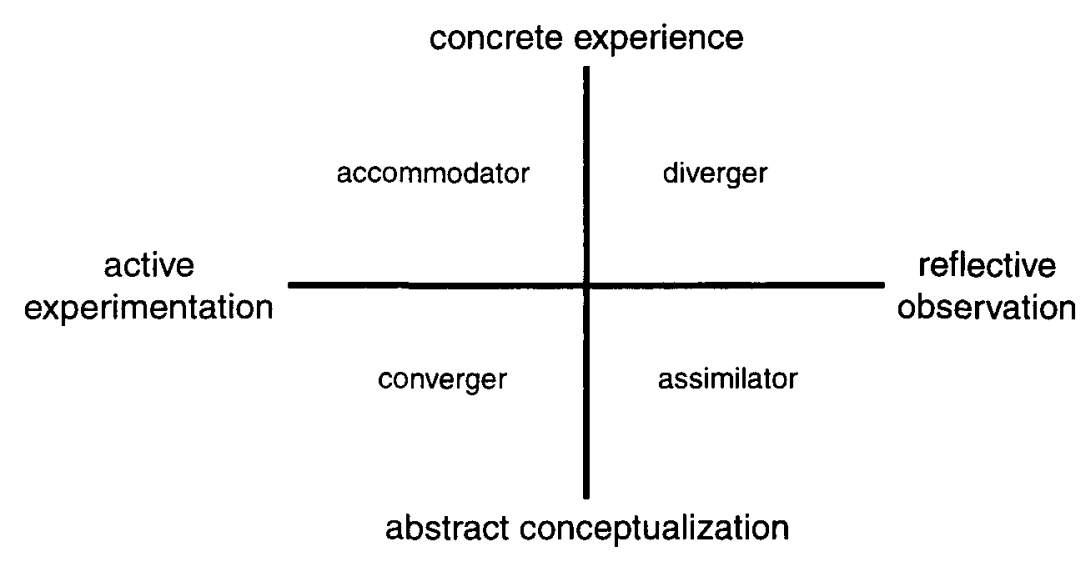

Source: Adapted from Kolb (1984).

score for any of the modes is 12 , and the highest is 48 . To determine an individual's placement on the graph in Figure 2, the score for abstract learning is subtracted from the score for concrete learning and the score for active learning is subtracted from the score for reflective learning. The raw scores for each student are then plotted along the two continuums mentioned above to determine the learning style of each student.

The LSI Scores for students in this study indicated a fairly even distribution among preferences for the four learning styles of the student population in this study. However, there were slightly more assimilators than any other types of learner. This difference was statistically significant. In Table 1 we present the learning styles of the students in our sample as a whole and broken down by sex, major, student level, and course level.

One of the most striking differences that emerged from the data presented in Table 1 was between men and women. One third of the women in the study identified themselves as accommodators, while less than $15 \%$ of male students did the same (significant at $\mathrm{p}<.01$ ). This may put women students at a disadvantage in political science classes, since the accommodator prefers active experimentation and concrete experience while most political science courses cater to abstraction and reflection, thus favoring the learning styles of the male students. The female students' preference for the accommodator learning style (a style that emphasizes personal involvement in learning) is consistent with the literature on gender socialization (Baxter 1989; Belenky, et al. 1986; Miller 1986).

Turning to the students' majors, there were differences among students with different major areas of study as expected from Kolb's findings (1984). Within the pool of social science students, political science and non-political science majors were quite similar in their learning preferences. Among political science majors, there were a higher number of assimilators than any other types of learners (this difference was of borderline statistical significance at $p<.10$ ). Physical science and engineering students in this study were more likely to be convergers and divergers. This coincides with the problem-solving and practical application emphasis of their chosen academic disciplines. However, the number of engineering and physical science majors (4 and 14, respectively) in this study was very small. Not surprisingly, LSI results of the humanities students indicated that they prefer learning styles that rely upon reflection (i.e., divergers and assimilators) rather than action (i.e., convergers and accommodators). 
In terms of student class level, there was a clear trend in preferences between upper and lower division students. Juniors and seniors were more likely to identify themselves as convergers and assimilators, the types of learners who favor abstraction over concrete experience. The inverse of this was true for freshmen and sophomores, who had a greater tendency to identify themselves as accommodators and divergers, the types of learners who favor concrete action over abstraction. These trends in student preferences were not statistically significant, but ultimately the difference of means tests were performed with very small subsets of the sample. Thus we feel that the differences are descriptively important. As we will discuss below, these differences potentially suggest the need to take a different pedagogical approach to upper and lower division classes.

\section{Discussion and Conclusions}

Overall, this study showed that student preferences were fairly evenly distributed among the four Kolb learning styles. Yet, political science classes along with most in the social science disciplines, traditionally rely on teaching methods that favor abstract and reflective learning (e.g., lecture, papers, models, discussion and thought questions). To accommodate the learning preferences of students who prefer active and concrete styles, a wider variety of teaching/learning activities needs to be included in the instructional design of traditional courses. Figure 3 identifies the various learning methods that can be employed to teach more directly to each of the four learning modes in the Kolb model.

A number of these learning activities can be employed within a single class session or interspersed throughout an entire course. A more systematic approach would be to follow the four stages of the Experiential Learning Cycle in single class or whole course design (Harb et al. 1995; Sims and Sims 1995). The first stage is Concrete Experience. It involves the introduction of specific course material, principles, or con-

TABLE 1. Learning Styles of Students in Political Science Courses

\begin{tabular}{|c|c|c|c|c|}
\hline & $\begin{array}{c}\text { Accommodator } \\
\text { (55) }\end{array}$ & $\begin{array}{c}\text { Converger } \\
\text { (53) }\end{array}$ & $\begin{array}{c}\text { Assimilator } \\
\text { (77) }\end{array}$ & $\begin{array}{c}\text { Diverger } \\
\text { (58) }\end{array}$ \\
\hline All Students ${ }^{a}$ (243) & $23 \%$ & $22 \%$ & $32 \%$ & $24 \%$ \\
\hline \multicolumn{5}{|l|}{ Gender: $^{b}$} \\
\hline Male (122) & 13 & 27 & 34 & 26 \\
\hline Female (113) & 33 & 16 & 29 & 22 \\
\hline \multicolumn{5}{|l|}{ Area of Major: ${ }^{c}$} \\
\hline Political Science (132) & 21 & 22 & 33 & 24 \\
\hline Other Social Science (58) & 28 & 24 & 28 & 21 \\
\hline Humanities (24) & 25 & 13 & 46 & 17 \\
\hline Physical Science (14) & 14 & 21 & 14 & 50 \\
\hline Engineering (4) & 0 & 50 & 25 & 25 \\
\hline \multicolumn{5}{|l|}{ Student Level: ${ }^{\text {d }}$} \\
\hline Freshman (52) & 21 & 22 & 29 & 29 \\
\hline Sophomore (62) & 24 & 21 & 29 & 26 \\
\hline Junior (60) & 25 & 30 & 33 & 22 \\
\hline Senior (44) & 14 & 30 & 37 & 19 \\
\hline \multicolumn{5}{|l|}{ Class Division: ${ }^{e}$} \\
\hline Lower (139) & 24 & 23 & 28 & 23 \\
\hline Upper (104) & 21 & 18 & 36 & 24 \\
\hline
\end{tabular}

Notes: Of the 260 students surveyed, 243 produced usable surveys. Within each category, two-tail difference of means tests were used to determine statistical significance. The following significant relationships emerged.

a“All Students": in the entire sample there were more assimilators than accommodators $(p<.05)$, convergers $(p<.05)$, and divergers $(p<.06$, borderline significance).

b"Gender": among males, there were fewer accommodators than all other types of learners (all significant at $p<.05$ ). Among females, there were more accommodators than convergers $(p<.01)$ and assimilators $(p<.05)$. There were also more female assimilators than convergers $(p<.05)$. Comparing across genders, there were more female accommodators than male accommodators $(p<.01)$, and more male convergers than female convergers $(p<.05)$.

c"Area of Major": among political science majors there were more assimilators than accommodators $(p<.05)$ and convergers $(p<.06$, borderline significance). Because of the small $\mathrm{N}$ in the other majors, significance tests were not useful. d"Student Level": among seniors, there were more assimilators than accommodators $(p<.05)$ and divergers $(p<.06$, borderline significance).

e"Class Division": among upper division students, there were more assimilators than accommodators $(p<.05)$, convergers $(p<.01)$, and divergers $(p<.07$, borderline significance).

cepts through the use of samples, examples, artifacts, videos, or actual data collection by students. In the second stage, Reflective Observation, students would be asked to discuss, read, write, or otherwise reflect on their experiences during the previous stage. In the Abstract Conceptualization stage, students would be ready to begin theory building, problem solving, or isolating relevant variables. This is an excellent stage for collaborative group work. Finally, in the Active Experimentation stage, students would begin to test their hypotheses, confront problems drawn from real life situations, and make decisions based on what they learned during the previous stages of study.

Teaching to all learning styles within the course of any instructional period avoids the problem of deciding whether it is more productive to match or mismatch instruction to learning styles. Historically, there have been attempts to design instructional programs that match 
learning styles with teaching styles, but research findings regarding the learning effectiveness of matching and mismatching are conflicting (Claxton and Murrell 1987). It is our position that matching instruction to learning styles of students in at least a portion of classes can increase student sense of belonging within a particular course, discipline, and institution (see also Kolb 1984). Matches and, perhaps more strongly, mismatches of learning styles can affect a students' social adaptation to academic life and to their identities as successful learners. Success in college, particularly for lower division students, has been linked to how well students assimilate into the college environment. For example, Tinto's (1993) research suggests that colleges and universities fail to retain students, particularly traditionally underrepresented students, because they do not make concerted efforts to incorporate those students into the academic life of the college or university. Too often, when students feel they do not fit, they do not stay.

Conversely, the concept of matching styles has been criticized as too simplistic. Critics of such strategies contend that they foster the misbelief that learning styles are static preferences (see Hyman and Rosoff 1984). Some reviewers of the literature on learning styles suggest that what has not been examined is the interaction between the cognitive and affective dimensions of learning. This interaction may be more critical for learning than we realize, particularly for many women and for both genders in traditionally underrepresented racial and ethnic groups (Anderson and Adams 1992; Anderson 1995). Students who value a more relational style of learning need to be introduced to subject matter with concrete and active experiences before they are ready to reflect and to make abstract conceptualizations. Students with this type of learning preference tend to be the more traditionally underrepresented students. While our study sample was not large enough to include race or ethnicity as a variable, we did find a significant gender difference. Importantly, more female students than male students indicated a preference

\section{Figure 3 - Instructional Tools Supporting the Four Learning Modes}

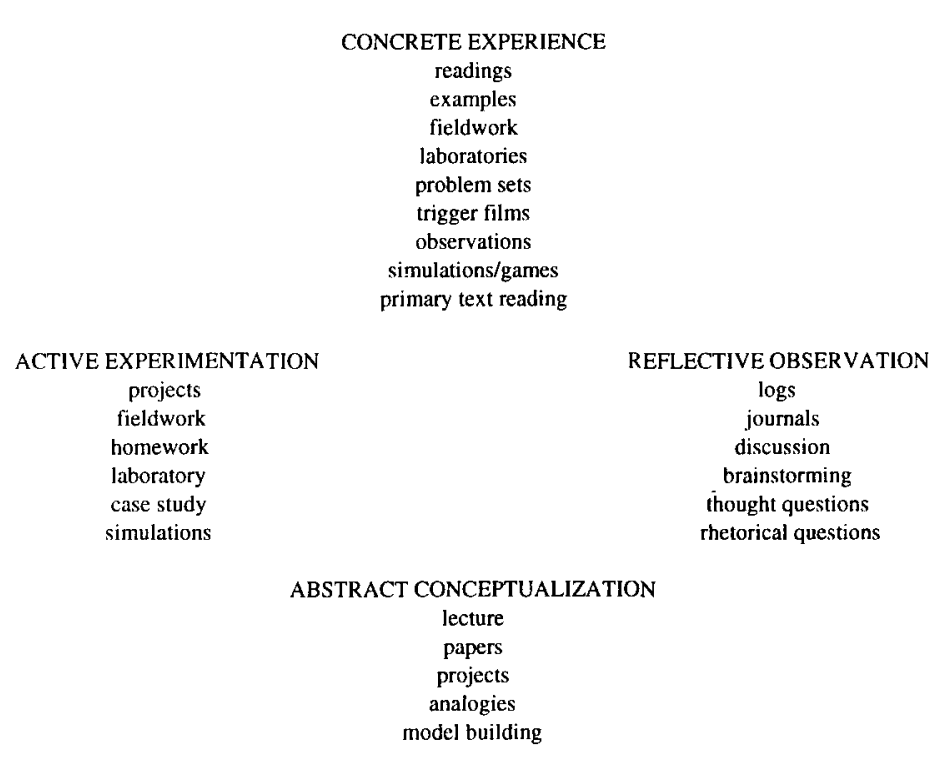

Source: Svinicki and Dixon(1987). Used by permission.

for concrete and active modes of learning.

Although the present study sample was too small to examine whether or not this gender difference diminishes as class level increases, we did find that more upper division students of both genders preferred reflective and abstract learning than did lower division students of both genders. This difference may result from the socialization experience of the academic environment and from the cognitive development that normally takes place as people mature. Of course, there are methods that can assist students in their development of abstract thinking. The literature concerning the stages of cognitive development can be of help in planning instruction to facilitate student's progression from dualistic type abstract thinking to more contexually based understandings of abstract concepts (see Perry 1970, 1981; Belenky, et al. 1986).

Our results suggest that in lower level introductory courses, a greater emphasis should be placed on activities that provide concrete and active experiences for students, since lower division students indicated a greater preference for these styles than up- perclass students. If one of the aims of lower division classes is to interest as many students as possible, particularly women and traditionally underrepresented students, in choosing political science as a major, or at least taking greater interest in politics regardless of the career field they choose, then this strategy could be beneficial toward meeting this goal.

When faculty vary instructional activities, students have an opportunity to demonstrate their skills and abilities to themselves, the instructor, and to their peers. For some, it may be a way of forming a positive relationship with an academic discipline that they would otherwise find dull, difficult, and uninteresting were it presented through only one method. Variation in instructional methods also requires students to practice skills they dislike or may find difficult, but to do so in a learning environment in which they can demonstrate their strengths and receive recognition for their accomplishments. Developing facility in all learning styles by all students should be professors' and students' ultimate goal. By exposing students to instructional methods that require the 
application of all the learning styles instructors can help students achieve this goal, gain greater confidence in their abilities (affective dimension), and simultaneously gain a wider range of skills (cognitive dimension).

\section{References}

Anderson, J.A. 1995. "Toward a Framework for Matching Teaching and Learning Styles for Diverse Populations." In The Importance of Learning Styles: Understanding the Implications for Learning, Course Design, and Education, ed. R.R. Sims and S.J. Sims. Westport, CT: Greenwood Press.

, and M. Adams, 1992. "Acknowledging the Learning Styles of Diverse Student Populations: Implications for Instructional Design." In Teaching for Diversity, ed. L.L.A. Border and N. Van Note Chism. New Directors for Teaching and Learning, No. 49. San Francisco: Jossey-Bass.

Baxter, M. B. 1989. "Gender Differences in Cognitive Development: An Analysis of Cognitive Complexity and Learning Styles." Joumal of College Student Development 30(3): 213-20.

Belenky, M.F., B.M. Clinchy, N.R. Goldberger, and J.M. Tarule. 1986. Women's Ways of Knowing: The Development of Self, Voice, and Mind. New York: Basic Books. Claxton, C.S., and P.H. Murrell. 1987. Learning Styles: Implications for Improving Edu- cational Practices. College Station, TX: Association for the Study of Higher Education.

Harb, J.N., R.E. Terry, P.K. Hurt, and K.J. Williamson. 1995. Teaching Through the Cycle: Application of Learning Style Theory to Engineering Education at Brigham Young University. 2nd ed. Provo, UT: Brigham Young University Press.

Hickcox, L.K. 1995. "Learning Styles: A Survey of Adult Learning Style Inventory Models." In The Importance of Learning Styles: Understanding the Implications for Learning, Course Design, and Education, ed. R.R. Sims and S.J. Sims. Westport, CT: Greenwood Press. . 1991. "Kolb's Experiential Learning Theory: An Historical Review and its Effects in Higher and Adult Education1971-1991." In An Historical Review of Kolb's Formulation of Experiential Learning Theory. Ph.D. diss. Oregon State University.

Hyman, R., and B. Rosoff. 1984. "Matching Learning and Teaching Styles: The Jug and What's in It." Theory Into Practice 23(1): 35-43.

Kolb, D.A. 1985. Learning Style Inventory. Boston: McBer and Co.

- 1984. Experiential Leaming: Experience as the Source of Learning and Development. Englewood Cliffs, NJ: Prentice-Hall.

Miller, J.B. 1986. Toward a New Psychology of Women. 2nd ed. Boston: Beacon Press.

Perry, W.G., Jr. 1970. Forms of Intellectual and Ethical Development in the College Years: A Scheme. New York: Holt, Rinehart, and Winston.

—. 1981. "Cognitive and Ethical Growth:
The Making of Meaning." In The Modem American College, ed. A.W. Chickering. San Francisco: Jossey-Bass.

Sims, R.R., and S.J. Sims. 1995. "Learning Enhancement in Higher Education." In The Importance of Learning Styles: Understanding the Implications for Learning, Course, Design, and Education, ed. R.R. Sims and S.J. Sims. Westport, CT: Greenwood Press.

Svinicki, M.D., and N.M. Dixon. 1987. "The Kolb Model Modified for Classroom Activities." College Teaching 35(4):141-46.

Tinto, V. 1993. Leaving College: Rethinking the Causes and Cures of Student Attrition. 2nd ed. Chicago and London: University of Chicago Press.

\section{About the Authors}

Richard L. Fox is an assistant professor of political science at Union College in Schenectady, New York. He is the author of Gender Dynamics in Congressional Elections (Sage, 1997).

Shirley A. Ronkowski, Ph.D., is an instructional Specialist in the Office of Instructional Consultation and Academic Coordinator for the campus-wide Teaching Assistant Development Program at the University of California, Santa Barbara. Her published articles, book chapters, and conference papers focus on instructional design, the scholarship of teaching, cooperative learning, and instructional technology for both current and future faculty.

\section{Numbers? Borrinnnggg!!!}

\section{William I. Buscemi, Wittenberg University}

How big is government anyway? Compared to what? How much does it spend? How many people work for it? Doing what? Should we cut welfare? Social Security? Should we reduce taxes? Balance the budget? Reduce the national debt? These questions dominate public discussion of politics, and should, it seems, figure heavily in any course on American government. Indications are, however, that they do not.

Students are more turned off from politics today than at any time since the 1950s (see Mann 1996). One reason for this lack of interest might be that the pressing issues of today, e.g., structural unemployment, welfare reform, and budget deficits, call for a different sort of understanding than did the issues of the $1960 \mathrm{~s}$ and 1970 s, e.g. school segregation, the Vietnam war, and Watergate. What appears as apathy and cynicism may be due in part to a lack of relevant conceptual tools with which to comprehend and judge important political events. To grasp today's issues one needs a sense of numbers; unfortunately, many students today would, if pressed, be hard put to describe the difference between a million and a billion. Why are students so innumerate with regard to the large numbers that figure into politics? I would suggest three factors that contribute to the problem. First of all, politicians, whose rhetoric fills much of the space available for political communication, have little in- centive to provide, and much reason to blur and evade, clear information concerning the magnitudes most relevant to the issue at hand. Rather than speak directly of unemployment rates or deficit figures, for instance, politicians often make reference to some incremental change over a time span selected to show themselves to advantage. Ross Perot, for all his faults, is to be commended for his attempts to provide, in clear and direct form, basic figures concerning such problems as the national debt. A second factor contributing to students' lack of interest in quantitative data may be, paradoxically, our own insistence as teachers on the highest standards of rigor and precision. We tend to disparage the 